\title{
PERBEDAAN SISTEM PENENTUAN AWAL BULAN SYAWAL 1427 H MASYARAKAT NAHDLIYYIN BANYUWANGI
}

\author{
Qorinatul Husna \\ UIN Maulana Malik Ibrahim Malang \\ Email: husna_qorin@yahoo.co.id
}

\begin{abstract}
Abstrak
The issue which is discussed in this paper is the cause of dualism difference on determining the beginning of syawal 1427 within NU organization including its sociological impact towards Nu's adherents in Banyuwangi. This research applies qualitative-naturalistic paradigm and sociological approach. $\mathrm{Nu}$ boards stated that the difference is caused by two factors. First, there is technical error in announcing the result of rukyat and the practice of rukyat itself. It shows that some of NU Board members already known in detail the situation and the main cause of determining the beginning of Syawal 1427 difference. As a result, there is a significant impact towards nahdliyyin that they believe in local religious figures in this matter. Another impact is that they are in doubt in performing iedul Fitri (first day of Syawal) as well as their fasting.

Permasalahan yang akan dibahas dalam tulisan ini adalah tentang penyebab terjadinya dualisme perbedaan penentuan awal bulan Syawal 1427 H di organisasi keagamaan NU beserta dampak sosiologis yang ditimbulkan terhadap masyarakat nahdliyyin Kec. Banyuwangi. Penelitian ini menggunakan paradigma naturalistik kualitatif dan menggunakan pendekatan sosiologis. Kalangan pengurus organisasi NU cabang Banyuwangi menganggap bahwa terdapat dua penyebab terjadinya perbedaan penentuan awal bulan Syawal 1427 H yang terjadi di organisasi keagamaan NU, yaitu: Adanya kesalahan teknis dalam penyebaran berita hasil rukyat dan adanya kesalahan dalam praktek rukyat. Hal ini menunjukkan bahwa beberapa pengurus organisasi keagamaan NU telah mengetahui secara rinci dan pasti mengenai runtutan peristiwa penyebab perbedaan penentuan awal bulan Syawal 1427 H yang terjadi di organisasi keagamaan NU. Tetapi terjadi dampak yang signifikan terhadap masyarakat nahdliyyin yang umumnya mereka hanya mampu bertaqlid kepada tokoh masyarakat setempat dan pengurus NU tanpa mengetahui dasar yang digunakan. Salah satu dampak tersebut antara lain: timbulnya keraguan dalam melaksanakan hari raya yang berdampak pada puasa mereka.
\end{abstract}

Kata Kunci: Perbedaan,Bulan, Nahdliyyin

Islam adalah ajaran sekaligus agama yang sempurna, membahas dan mengatur segala permasalahan bagi pemeluknya yang bersifat duniawi maupun ukhrawi beserta dengan solusi yang ditawarkannya. Manusia diciptakan tidak hanya sebagai kholifah fi al-ardh, melainkan juga dalam rangka beribadah kepada Allah. ${ }^{1}$ Karena hidup ini tidak hanya di dunia, melainkan kekekalan akan diperoleh ketika hidup di akhirat.

Keterkaitan yang sangat erat antara pelaksanaan ibadah dengan fenomena alam yang telah menjadi sunnatullah merupakan suatu kajian yang sangat menarik, yang merupakan bukti akan kesempurnaan

1 Q.S. al-Dzâriyat (51): 56 agama Islam. Segala bentuk pelaksanaan ibadah sangat dipengaruhi oleh perkembangan ilmu pengetahuan dan teknologi, seperti ibadah fardhu - dalam hal ini sholat, zakat, puasa Ramadhan dan haji - dipengaruhi dengan adanya waktu pelaksanaan.

Waktu merupakan sesuatu hal yang sangat penting dalam kehidupan manusia. Segala kegiatan manusia, baik yang bersifat pribadi maupun sosial, duniawi maupun ukhrawi, umum maupun keagamaan, semuanya tidak dapat dilepaskan dengan konteks waktu. ${ }^{2}$ Dalam al-Qur'an surat Yunus ayat 5 dan 6 Allah SWT berfirman:

2 Moh. Murtadho, Ilmu Hisab Praktis: Dasar-Dasar Falakiyah (Malang: Fakultas Syari'ah UIN Malang, 2004), 31. 


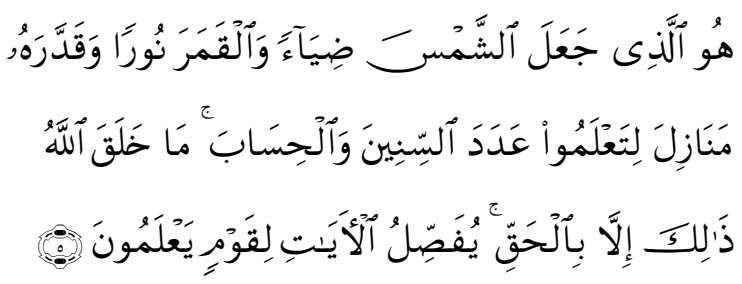

"Dia-lah yang menjadikan matahari bersinar dan bulan bercahaya, dan ditetapkannya manzilahmanzilah (tempat-tempat) bagi perjalanan bulan itu, supaya kamu mengetahui bilangan tahun dan perhitungan (waktu). Allah tidak menciptakan yang demikian itu melainkan dengan hak. Dia menjelaskan tanda-tanda (kebesaran-Nya) kepada orang-orang yang mengetahui. Sesungguhnya pada pertukaran malam dan siang itu dan pada apa yang diciptakan Allah di langit dan di bumi, benar-benar terdapat tanda-tanda (kekuasaan-Nya) bagi orang-orang yang bertaqwa".

Dari ayat di atas jelaslah bahwa Allah SWT menjadikan semua yang disebutkan itu tidaklah percuma, tetapi dengan penuh hikmah. Allah juga menerangkan tanda-tanda kekuasaan-Nya, termasuk matahari dan bulan, siang dan malam serta peredaran benda langit lainnya yang dengannya dapat diketahui bilangan tahun dan perhitungannya.

Sejak awal peradaban, manusia sudah merasakan perlunya sistem pembagian waktu menjadi satuan-satuan "bulan" dan "tahun" yang lazim disebut kalender. Kebutuhan manusia akan sistem kalender itu sangat berpengaruh terhadap kepentingan kehidupan seharihari dan keagamaan. Acuan yang digunakan untuk menyusun kalender tersebut adalah siklus pergerakan dua benda langit yang sangat besar pengaruhnya pada kehidupan manusia, yaitu bulan dan matahari. Kalender yang disusun berdasarkan siklus sinodik bulan dinamakan kalender bulan (Qomariyah, Lunar) dan yang berdasarkan siklus tropik matahari dinamakan kalender matahari (Syamsiyah, Solar). ${ }^{4}$

Satu tahun Syamsiyah lamanya 365 hari untuk tahun-tahun pendek dan 366 hari untuk tahun panjang, sedangkan tahun Qomariyah lamanya 354 hari untuk tahun pendek dan 355 hari untuk tahun panjang. Dengan demikian perhitungan tahun Qomariyah akan lebih cepat sekitar 10 sampai 11 hari setiap tahun, jika dibandingkan dengan perhitungan tahun Syamsiyah. ${ }^{5}$

\footnotetext{
3 Program al-Qur'an in word.

4 Abd. Salam Nawawi, Rukyat Hisab di Kalangan NU Muhammadiyah (Surabaya: Diantama dan Lajnah Falakiyah NU Jatim, 2004), 1-2.

5 Pedoman Perhitungan Awal Bulan Qomariyah: Dengan Ilmu Ukur Bola (Jakarta: Pembinaan Administrasi Hukum dan Peradilan Agama, 1983), 1.
}

Dalam Islam, peredaran akan dua benda langit tersebut dapat dipelajari melalui ilmu falak.

Ilmu falak ditemukan dalam kurun waktu ribuan tahun, dimulai sejak kurang-lebih 3000 tahun sebelum Masehi di Kerajaan Babilonia yang terletak di antara Sungai Tigris dan Sungai Efrat (selatan Irak kini). ${ }^{6}$ Ilmu falak merupakan ilmu astronomi, yang dasar perhitungannya berasal dari teori-teori matematika. Mempelajari ilmu falak pada dasarnya mempunyai dua kepentingan yang saling berkaitan: pertama, untuk penguasaan dan pengembangan ilmu pengetahuan dan teknologi; kedua, untuk keperluan yang berkaitan dengan masalah-masalah ibadah, seperti sholat, puasa dan haji. Keperluan ini bersifat pragmatis dan turut menentukan sahnya amal ibadah. Keperluan yang kedua ini meliputi: penentuan awal bulan Qomariyah untuk puasa, haji, dan hari-hari besar Islam. ${ }^{7}$

Penentuan awal bulan dalam kalender Qomariyah sangatlah menarik perhatian bagi umat Islam, terutama kalau diprediksikan akan terjadi perbedaan dalam penetapannya. Perbedaan penetapan awal bulan Qomariyah di Indonesia ternyata terjadi karena beberapa faktor yang mempengaruhinya, antara lain adalah adanya perbedaan sistem penetapan awal bulan antara hisab dan rukyat, juga karena adanya metode yang berbeda sebagai acuannya. Apabila dicermati, tidak kurang dari 100 buah hadits - yang diriwayatkan oleh Bukhari, Muslim, Abu Daud, an-Nasa'i, Ibnu Majah, at-Tirmidzi, Imam Malik, Imam Hambali, dan lain-lain - memberikan petunjuk bahwa untuk menentukan masuknya bulan Qomariyah, dengan tiga cara, yaitu (1) rukyat al-hilâl, (2) istikmâl iddah al-syahr dan (3) men-takdir-kan (memperkirakan dengan ilmu hisab), hanya cara yang ketiga ini masih diperselisihkan oleh fuqaha' ${ }^{8}$

Dalam penentuan awal bulan Qomariyah di Indonesia, hanya beberapa bulan tertentu yang menjadi perbedaan dalam penentuannya. Seperti penentuan awal bulan Ramadhan, awal bulan Syawal, dan awal bulan Dzulhijjah. Penentuan beberapa awal bulan tersebut sangat penting artinya bagi segenap umat Islam, sebab banyak ibadah dalam Islam yang pelaksanaannya dikaitkan dengan perhitungan awal bulan. ${ }^{9}$

Hal yang sama juga terjadi di Kecamatan Banyuwangi. Hal ini disebabkan ada dua organisasi ke-

\footnotetext{
6 Abdul Aziz Dahlan (ed.) et. al., Ensiklopedi Islam (Jakarta: PT. Ichtiar Baru van Hoeve), 136.

7 Abdul Aziz Dahlan (ed.) et. al., Ensiklopedi Hukum Islam (Jakarta: PT. Ichtiar Baru van Hoeve, 2001), 306.

8 Moh. Murtadho, Jurnal Ilmiah eL-Qisth, Volume 2, Nomor 1, September 2005 (Malang: Fakultas Syari'ah UIN Malang, 2005), 30.

9 Almanak Hisab Rukyat (Jakarta: Proyek Pembinaan Badan Peradilan Agama Islam, 1981), 98.
} 
agamaan yang mendominasi dalam masyarakatBanyuwangi, yaitu organisasi keagamaan Muhammmadiyah dan organisasi keagamaan Nahdlatul Ulama (NU). Dalam menentukan awal bulan Qomariyah khususnya awal Syawal, keduanya menggunakan metode yang berbeda. Sehingga kurang lebih selama lima belas tahun terakhir, terjadi perbedaan dalam melaksanakan hari raya.

Seperti tahun-tahun sebelumnya, pada hari raya Idul Fitri tahun $1427 \mathrm{H}$ kemarin juga terjadi perbedaan. Organisasi keagamaan Muhammadiyah dengan menggunakan metode hisab menentukan bahwa awal bulan Syawal $1427 \mathrm{H}$ jatuh pada hari senin tanggal 23 Oktober 2006. Akan tetapi ada hal yang menarik dikalangan NU yang tidak pernah terjadi sebelumnya, hal ini disebabkan karena adanya dualisme perbedaan penentuan awal Syawal $1427 \mathrm{H}$ antara Pengurus Besar NU Pusat dengan Pengurus wilayah NU Jawa Timur. Pengurus wilayah NU Jawa Timur, setelah menerima laporan bahwa hilâl berhasil dirukyat di pantai Gebang ${ }^{10}$ Bangkalan dan di pantai Cakung Jakarta yang mengikhbarkan lebih awal sebelum datangnya berita itsbat dari pemerintah dan PBNU, mengatakan bahwa awal bulan Syawal 1427 $\mathrm{H}$ jatuh pada hari Senin tanggal 23 Oktober $2006^{11}$. Sedangkan itsbat yang dikeluarkan dalam sidang yang diadakan oleh Menteri Agama yang datangnya 1 jam setelah ikhbar PWNU Jawa Timur tetap menggunakan istikmâl $^{12}$ sebagai solusi terakhirnya. Dengan dasar penyelenggaraan rukyat di seluruh Indonesia tidak berhasil melihat hilâl dan didukung dengan data hisab yang tinggi akurasinya dari mayoritas metode atau sistem hisab. Atas dasar tersebut maka Pengurus Besar NU menentukan awal bulan Syawal 1427 H jatuh pada hari selasa tanggal 24 Oktober $2006 .{ }^{13} \mathrm{Hal}$ ini senada dilakukan oleh pemerintah yang secara kebetulan sesuai dengan kalender yang ada.

Dualisme keputusan yang terjadi di kalangan NU Kecamatan Banyuwangi inilah yang menjadi hal menarik untuk ditelaah lebih jauh. Hal ini karena peristiwa semacam ini secara sosiologis cukup berdampak pada keresahan kehidupan beragama, bahkan berimplikasi pada berbagai aktivitas sosial kemasyarakatan di Kecamatan Banyuwangi dalam skala luas. Banyaknya sistem dan metode yang digunakan dalam penetapan awal bulan Syawal sebagaimana di atas, mempunyai pengaruh secara langsung pada masya-

\footnotetext{
10 Pada pembahasan selanjutnya disingkat P. Gebang.

11 Ikhbar Pengurus Wilayah Nahdlatul Ulama Jawa Timur, 22 Oktober 2006.

12 Menyempurnakan tiga puluh hari dalam satu bulan.

13 Ikhbar Pemberitahuan Hasil Rukyatul Hilal bil Fi'li Awal Syawal 1427 H oleh PBNU, 22 Oktober 2006
}

rakat khususnya mengenai masalah ibadah yang berdampak pada ritual keagamaan maupun ukhuwah Islamiah. Salah satu contoh fenomena yang terjadi di Kelurahan Tukangkayu, salah seorang yang tinggal di kawasan basis NU tersebut menjalankan sholat Idul Fitri pada hari Senin tanggal 23 Oktober 2006, padahal mayoritas masyarakat sekitar masih menjalankan ibadah puasa di hari terakhir bulan Ramadhan. Karena perbedaannya dalam menjalankan shalat Idul Fitri, orang tersebut menjadi bahan gunjingan masyarakat sekitar. $^{14}$

Fenomena perbedaan tersebut bisa menjadi faktor penyebab keraguan akan keabsahan ibadah yang mereka laksanakan serta memungkinkan terjadi dampak yang signifikan, misalnya adanya keraguan keyakinan dalam diri seseorang terkait pelaksanaan hari raya. Hal ini karena letak Kecamatan Banyuwangi berada di tengah kota Banyuwangi, sebagian besar mereka menganggap kurang penting pendidikan agama. Sehingga sangatlah wajar jika mereka awam tentang masalah hisab dan rukyat. Ketidaktahuan mereka terhadap hisab dan rukyat yang menjadi metode penentuan awal bulan Syawal menyebabkan mayoritas dari mereka hanya mampu mengikuti organisasi-organisasi keagamaan yang ada dan tokoh masyarakat di lingkungan sekitar tanpa mengetahui dasar yang digunakan - dalam istilah Islam dikenal dengan taqlid -.

Melihat fenomena sosiologis yang ada, maka penulis merasa tertarik untuk meneliti dan memahami lebih lanjut dampak sosiologis pada masyarakat nahdliyyin $^{15}$ akibat perbedaan sistem penentuan awal bulan Syawal 1427 H. Untuk itu dalam kesempatan ini, judul yang diangkat dalam penelitian adalah "Dampak Sosiologis Perbedaan Sistem Penentuan Awal Bulan Syawal 1427 H Terhadap Masyarakat Nahdliyyin Kecamatan Banyuwangi".

Berdasarkan latar belakang masalah di atas, maka permasalahan yang dibahas adalah (1) Apa penyebab perbedaan penentuan awal bulan Syawal 1427 $\mathrm{H}$ dalam organisasi keagamaan NU di Kecamatan Banyuwangi?, (2) Apa saja dampak sosiologis yang terjadi terhadap masyarakat nahdliyyin Kecamatan Banyuwangi terkait dengan perbedaan penentuan awal bulan Syawal 1427 H?

Tujuan penelitian ini adalah (1) Memahami penyebab perbedaan penentuan awal bulan Syawal

\footnotetext{
14 Informasi diperoleh melalui pengamatan terhadap aktifitas dan mengetahui proses bagaimana terjadi reaksi masyarakat pada saat itu secara pasti karena peneliti menyaksikan sendiri secara langsung.

15 Sebutan yang biasa ditujukan untuk orang-orang yang merasa mengikuti organisasi keagamaan NU.
} 
1427 H dalam organisasi keagamaan NU Kecamatan Banyuwangi, (2) Memahami dampak sosiologis yang terjadi terhadap masyarakat nahdliyyin Kecamatan Banyuwangi terkait dengan perbedaan awal bulan Syawal $1427 \mathrm{H}$.

\section{Metode Penelitian}

Paradigma dalam penelitian ini adalah naturalistik kualitatif. Paradigma ini menekankan hakikat kenyataan sosial yang didasarkan pada definisi subyektif dan penilaiannya. ${ }^{16}$ Struktur sosial menunjuk pada definisi bersama yang dimiliki individu yang berhubungan dengan bentuk-bentuk yang cocok yang menghubungkannya satu sama lain.

Pendekatan yang digunakan adalah sosiologis. Objek penelitian agama dengan pendekatan sosiologis menurut Keith A. Robert menfokuskan pada: ${ }^{17}$ (1) kelompok-kelompok dan lembaga keagamaan. Dalam hal ini difokuskan pada organisasi keagamaan NU yang ada di Kecamatan Banyuwangi; (2) perilaku individu dalam kelompok-kelompok tersebut. Penelitian ini difokuskan pada perilaku keseharian yang dilakukan oleh masyarakat nahdliyyin yang mendominasi di Kecamatan Banyuwangi; (3) konflik antar kelompok.

Sedangkan metode yang digunakan dalam penelitian ini adalah studi kasus kontemporer atau studi kasus observasi. Metode ini menekankan keadaan sekarang (saat penelitian dilangsungkan). ${ }^{18}$ Fokus studi dalam penelitian ini adalah organisasi keagamaan NU dan masyarakat nahdliyyin di Kecamatan Banyuwangi.

Dalam penelitian kualitatif, ketepatan memilih dan menentukan jenis sumber data akan menentukan kekayaan data yang diperoleh. Jenis sumber data terutama dalam penelitian ini dapat diklasifikasikan sebagai berikut: ${ }^{19}$ (1) Narasumber (informan) dalam penelitian ini yaitu Ahmad Muslim, Ali Makki, Nur Hariri, Amin Asy'ari, Masykur Ali sebagai pengurus organisasi keagamaan NU. Wiyono, Sapuan, Suratmin, Abdurrahman, Ina, Masidah, Latifah, Apid, Aminah, Masruroh sebagai masyarakat Kelurahan Tukangkayu, masyarakat Kelurahan Karangrejo, masyarakat Kelurahan Panderejo yang didominasi oleh masyarakat nahdliyyin. Serta Maksum, Abdul Hadi, Abdul Nasir sebagai tokoh masyarakat di Kecamatan Banyuwangi, (2) Peristiwa atau aktivitas ini, peneliti bisa mengetahui proses bagaimana terjadi perbedaan

\footnotetext{
16 Imam Suprayogo dan Tobroni, Metodologi Penelitian Sosial-Agama (Bandung: PT Remaja Rosdakarya, 2003), 94.

17 Ibid., 61.

18 Ibid., 139

19 Ibid., 163.
}

awal Syawal 1427 H di Kecamatan Banyuwangi dan reaksi masyarakat pada saat itu secara pasti karena menyaksikan sendiri secara langsung. Dengan mengamati peristiwa, peneliti dapat melakukan cross check terhadap informan verbal yang diberikan oleh sebjek yang diteliti, (3) Tempat atau lokasi penelitian tentang dampak sosiologis perbedaan sistem penentuan awal Syawal 1427 Hpadamasyarakatnahdliyyin Kecamatan Banyuwangi, sebagian informasinya dapat digali dari pengamatan langsung ke Kelurahan-kelurahan tersebut dan organisasi keagamaan NU di Kecamatan Banyuwangi, dan (4) Dokumen dalam penelitian ini berupa arsip dan catatan tentang daftar isian data dasar profil Kelurahan tahun 2006 Kecamatan Banyuwangi Kabupaten Banyuwangi, serta beberapa rekaman yang diperoleh ketika penelitian. Selain itu data-data atau arsip-arsip dan beberapa surat dari organisasi keagamaan NU di Kecamatan Banyuwangi tentang perbedaan awal Syawal $1427 \mathrm{H}$.

Dalam memperoleh informasi, diperlukan sumber data berupa orang (informan), peristiwa dan lokasi, benda, dokumen, atau arsip..$^{20}$ Teknik pengumpulan data penelitian ini adalah (1) Observasi dalam penelitian ini dilakukan di lingkungan Maksum, Abdul Hadi, Abdul Nasir yang merupakan tokoh masyarakat. Wiyono, Sapuan, Suratmin, Abdurrahman, Ina, Masidah, Latifah, Apid, aminah, Masruroh yang merupakan masyarakat nahdliyyin yang ada di Kelurahan Tukangkayu, Kelurahan Karangrejo dan Kelurahan Panderejo dan Ahmad Muslim, Ali Makki, Nur Hariri, Amin Asy'ari, Masykur Ali sebagai pengurus organisasi keagamaan NU Kecamatan Banyuwangi, (2) Dalam penelitian ini, dilakukan wawancara dengan Ahmad Muslim, Ali Makki, Amin Asy'ari, Nur Hariri, Masykur Ali pengurus organisasi keagamaan NU yang mengetahui penyebab terjadinya perbedaan di organisasi keagamaan NU. Maksum, Abdul Hadi, Abdul Nasir sebagai tokoh masyarakat. serta Wiyono, Sapuan, Suratmin, Abdurrahman, Ina, Masidah, Latifah, Apid, Aminah, Masruroh sebagai masyarakat nahdliyyin yang ada di Kelurahan Tukangkayu, kelurahan Karangrejo, dan Kelurahan Panderejo Kecamatan Banyuwangi.

\section{Pengolahan dan Analisis Data}

Data-data yang diperoleh di lapangan selama penelitian diolah dengan tahapan-tahapan adalah editing (pemeriksaan ulang) dengan tujuan data yang dihasilkan berkualitas baik, ${ }^{21}$ classifying

20 Ibid., 167.

21 LKP2M, Research Book For LKP2M (Malang: UIN-Malang, 2005), 60. 
(pengelompokan) dimana data hasil wawancara diklasifikasikan berdasarkan kategori tertentu, analisying (analisis) akan dilakukan dengan menggunakan teoriteori yang telah dipaparkan diantaranya menggunakan teori falak tentang sistem yang digunakan dalam menentukan awal bulan Qomariyah khususnya Syawal dan menjelaskan itsbat dan ikhbar yang terdapat di organisasi keagamaan NU, dan concluding (penarikan kesimpulan) dari data-data yang telah diolah untuk mendapatkan jawaban. ${ }^{22}$ Dalam proses ini penulis menyimpulkan hasil temuan-temuan dari lapangan untuk menjawab permasalahan dalam rumusan masalah.

\section{Hasil dan Pembahasan}

Penyebab Perbedaan Penentuan Awal Bulan Syawal 1427 H Dalam Organisasi Keagamaan Nu Di Kecamatan Banyuwangi

Suasana pada waktu hari raya $1427 \mathrm{H}$ di Indonesia terasa kurang "kompak". Hal ini disebabkan terdapat perbedaan dalam menentukan tanggal 1 Syawal 1427 $\mathrm{H}$ diantara beberapa organisasi keagamaan di Indonesia. Hal yang sama juga terjadi di Kecamatan Banyuwangi. Ada dua organisasi keagamaan yang mendominasi dalam masyarakat Banyuwangi, yaitu organisasi keagamaan Muhammmadiyah dan organisasi keagamaan Nahdlatul Ulama (NU). Dalam menentukan awal bulan Qomariyah khususnya awal Syawal, keduanya menggunakan metode yang berbeda. Sehingga kurang lebih selama lima belas tahun terakhir, terjadi perbedaan dalam melaksanakan hari raya.

Dalam penentuan awal bulan Syawal 1427 $\mathrm{H}$, terjadi dualisme perbedaan penentuan di dalam organisasi keagamaan NU yang menyebabkan berbeda pula dalam melaksanakan hari raya Idul Fitri. Dengan adanya dualisme perbedaan keputusan di dalam organisasi NU, kantor NU terpaksa harus buka sampai pagi karena banyak masyarakat nahdliyyin yang mencari kejelasan tentang kapan kepastian mereka diperbolehkan melaksanakan hari raya. Hal ini mengakibatkan banyak pengurus organisasi keagamaan NU cabang Banyuwangi yang "menghindari" dengan berbagai cara karena mereka tidak sanggup menanggung akibatnya. ${ }^{23}$

Berdasarkan data-data yang ditemukan di lapangan, terdapat beberapa pendapat penyebab dualisme perbedaan penentuan awal Syawal $1427 \mathrm{H}$ yang terjadi dalam organisasi keagamaan NU. Pendapat ini

\footnotetext{
22 Nana Sudjana dan Ahwal Kusuma, Proposal Penelitian di Perguruan Tinggi (Bandung: Sinar Baru Algasindo, 2001), 89.

23 Masykur, wawancara, 22 September 2007.
}

berasal dari beberapa pengurus organisasi keagamaan NU yang sedikit banyak mengetahui tentang hisab dan rukyat. Bahkan ada beberapa diantara mereka sudah memiliki jabatan yang berkompeten dalam bidang tersebut di organisasi keagamaan NU. Peneliti mengklasifikasikan penyebab terjadinya dualisme perbedaan penentuan awal bulan Syawal 1427 H di organisasi keagamaan NU menjadi dua, yaitu:

\section{Adanya Kesalahan Teknis Dalam Penyebaran Berita Hasil Rukyat}

Menurut beberapa pengurus organisasi keagamaan NU penyebab dari dualisme perbedaan penentuan awal bulan Syawal 1427 H karena adanya kesalahan teknis dalam penyebaran hasil rukyat yang dilaksanakan di P. Gebang. Sebagaimana Ahmad mengatakan,"Niki kesalahan teknis, niki wontene wilayah ngikhbaraken niku semua tempat tidak berhasil, tapi beliau merasa berhasil di Gebang Madura yaitu pak KH. Ghozali. Padahal hasil rukyat kulo tidak bisa dilihat." (Ini kesalahan teknis, padahal wilayah mengikhbarkan bahwa semua tempat tidak berhasil, tapi beliau merasa berhasil di Gebang Madura yaitu pak KH. Ghozali. Padahal hasil rukyat saya tidak bisa dilihat). ${ }^{24}$

Hal senada juga dikatakan oleh Ali dalam penuturannya:

"Pada waktu itu tim PWNU yang ada di Bangkalan bersaksi bahwa ia melihat bulan. Kalo pada waktu itu hitungan semua metode ya tidak mungkin dirukyat karena sangat rendah di bawah 2 derajat ketinggian hilalnya dari ufuk. Karena di NU hisab itu karena wong penuntun untuk rukyat, karena di hisab itu kan dihitung posisi hilal dimana, lintang selatannya, lintang utaranya, itu kan penuntun semua itu. Sekedar penuntun maka disini kalo ada kenyataan yang berbeda, baru disini terjadi perbedaan. Penuntunnya mengatakan A semua tapi kenyataannya di Bangkalan itu ternyata B, lah disini terjadi perbedaan, lah perbedaan itu akhirnya kan kalo rukyat seperti itu kan yang dipegang rukyatnya. Sementara hasil rukyat ini oleh PB masuknya juga telat, yang saya tahu begitu. Akhirnya $P B$ sudah ngirim fax mengumumkan hari rayanya adalah hari selasa. ${ }^{25}$

24 Ahmad, wawancara, 22 September 2007.

25 Ali, wawancara, 22 September 2007. 
Statemen-statemen di atas mengatakan bahwa mereka menganggap sebuah kesalahan proses untuk memberitahukan hasil rukyat yang menyebabkan perbedaan penentuan tersebut, menunjukkan bahwa beberapa pengurus organisasi keagamaan NU telah mengetahui secara rinci dan pasti mengenai runtutan peristiwa penyebab perbedaan penentuan awal bulan Syawal $1427 \mathrm{H}$ yang terjadi di organisasi keagamaan NU. Disini menunjukkan bahwa mereka tidak dengan mudahnya taqlid begitu saja tanpa mengetahui alasan yang kuat. Dengan mereka membuktikan dan mengetahui secara langsung, mereka dapat menjelaskan kepada masyarakat nahdliyyin. Sebab masyarakat nahdliyyin pasti akan menanyakan dan taqlid kepada mereka. Hal ini terlihat adanya pemahaman yang terinternalisasi dengan baik bahwa sebagai pengurus NU dan sebagai tauladan masyarakat nahdliyyin khususnya dan masyarakat lain umumnya, sudah bukan saatnya untuk taqlid dan pasrah terhadap keputusan dari NU pusat. Akan tetapi justru mereka harus berijtihad dengan kemampuan keilmuan yang mereka miliki.

Mereka juga meragukan kevalidan hasil rukyat yang dilaksanakan di P. Gebang. Tentunya keraguan mereka ini dengan berdasarkan pembuktian yang mereka lakukan bahwa dengan menggunakan semua metode hisab tidak mungkin di rukyat dan rukyat yang mereka lakukan pun tidak berhasil. Karena hasilnya ketinggian hilal dari ufuk masih di bawah $2^{\circ}$ (derajat).

Sebagaimana ditulis oleh Lajnah Falakiyah Pengurus Besar Nahdlatul Ulama dalam bukunya, almanak PBNU tahun 2006 yang diterbitkan oleh LFNU telah menginformasikan bahwa tanggal 29 malam 30 Ramadhan $1427 \mathrm{H}$ bertepatan dengan tanggal 22 Oktober 2006 ketika matahari terbenam, tinggi hilal $0^{\circ}$ 54', ijtimak pukul 12:07:30, letak matahari terbenam $11^{\circ} 15^{\prime} \mathrm{STB}$, kedudukan hilal $3^{\circ} 38^{\prime}$ 'SM, lama hilal 3'13". Ini artinya belum memenuhi imkân alrukyat. Sedangkan pelaksanaan rukyat di seluruh Indonesia dikendalikan oleh Pengurus Pusat Lajnah Falakiyah Nahdlatul Ulama (PP LFNU). Sebelum Surabaya Maghrib, PP LFNU menginformasikan kepada koordinator rukyat Jawa Timur bahwa posisi hilal di Indonesia yang paling tinggi di Pelabuhan Ratu, yaitu $0^{\circ} 38^{\prime}$, sementara di sekitar bulan terdapat benda angkasa lain (Jupiter dan Merkurius) dan cahaya matahari 25 juta kali lebih kuat dari pada cahaya bulan yang lemah, sehingga hilal sulit dilihat. Informasi tersebut bertujuan agar PWNU Jawa Timur lebih berhati-hati dan teliti dalam melaporkan hasil rukyat. ${ }^{26}$

Pelaksanaan rukyat pada umumnya berjalan dengan baik. Terbukti dengan adanya laporan dari daerah-daerah yang lancar dan menyatakan tidak berhasil melihat hilal. Sementara laporan dari Jawa Timur sangat terlambat dibandingkan biasanya. Laporan pertama, datang 20 menit setelah laporan dari Lampung, menyatakan bahwa 11 lokasi rukyat tidak berhasil. Menyusul kemudian laporan dari KH. Hasan Basri yang menyatakan Gresik tidak berhasil. Selanjutnya di tengah sidang itsbat, masuk kembali laporan susulan dari Jawa Timur yang menyatakan Bangkalan berhasil melihat hilal. Terlepas dari salah atau benarnya informasi tersebut, terpaksa laporan diabaikan oleh PBNU dengan alasan karena terlambat. ${ }^{27}$

Hal lain juga mereka katakan bahwa yang berhak memberikan keputusan terkait hal tersebut adalah PBNU selaku pengurus pusat. Hal ini sesuai dengan apa yang diungkapkan Ali:

"Di NU ini, kalo hirarki organisasinya penentuan awal Syawal itu sesuai dengan keputusan muktamar, yang berhak memberikan keputusan ikhbar sesuai AD ART adalah PBNU".

Dan dikuatkan oleh penuturan Ahmad:

"Menurut aturan itsbat niku pihak pe-
merintah PB terus permasalahannya
kesalahan teknis PW membuat ikhbar
sebelum ikhbar dari PB. Kalo secara
organisasi ya menyalahi aturan." (me-
nurutaturan itsbatitu hakpemerintah PB
lalu permasalahannya adalah kesalahan
teknis dari PW yang membuat ikhbar
sebelum ikhbar dari PB. Kalau secara
organisasi menyalahi aturan)

Hal senada tertulis dalam buku Lajnah Falakiyah Pengurus Besar Nahdlatul Ulama yang mengatakan bahwa itsbat adalah hak dan wewenang pemerintah c.q. Menteri Agama untuk menetapkan awal Ramadhan, awal Syawal, dan awal Dzulhijjah. Sedangkan ikhbar adalah hak dan wewenang PBNU untuk memastikan dan menyiarkan ke seluruh Indonesia tentang awal Ramadhan, awal Syawal, dan awal Dzulhijjah sesudah sidang itsbat dan setelah mem-

\footnotetext{
26 Laporan Lajnah Falakiyah Kepada PBNU Tentang Penyelenggaraan Rukyat Untuk Idul Fitri 1427 H (Lajnah Falakiyah Pengurus Besar Nahdlatul Ulama, 2006), 2.

27 Ibid., 4.
} 
peroleh laporan dari Lajnah Falakiyah Nahdlatul Ulama mengenai hasil rukyat dan sidang itsbat. ${ }^{28}$

Berdasarkan SK PBNU Nomor: 311/A.II.04.d/ I/1994:

Pasal I ayat c:

"Bila penyelenggaraan rukyat tidak dimungkinkan karena satu dan lain hal, maka agar supaya Itsbatul Hakim dilakukan atas dasar aasil rukyat atau Istikmal, maka hasil rukyat yang telah dilakukan di kalangan Nahdlatul Ulama supaya sesegera mungkin dilaporkan kepada pemerintah c.q Departemen Agama RI untuk di itsbat. Pelaporannya bisa lewat PA (Pengadilan Agama) setempat atau langsung kepada Departemen Agama Pusat (Badan Hisab dan Rukyat)".

Hal ini tentu saja berbeda dengan fakta yang terjadi, ketika itsbat pemerintah dan PBNU mulai dikirim ke daerah, ternyata ikhbar PWNU Jawa Timur sudah beredar sekitar 1 jam sebelumnya bahkan sampai di luar pulau Jawa, terbukti banyak masyarakat nahdliyyin menanyakannya langsung ke PBNU. Inilah yang menyebabkan adanya dualisme tersebut. Oleh karena itu sangatlah wajar jika mereka mengatakan bahwa terjadi kesalahan teknik dalam penyebaran berita hasil rukyat terkait penentuan awal Syawal $1427 \mathrm{H}$.

Pendapat yang berseberangan juga muncul di kalangan pengurus NU yang lain. Amin salah satunya, beliau berpendapat,"Nabi sudah bersabda:

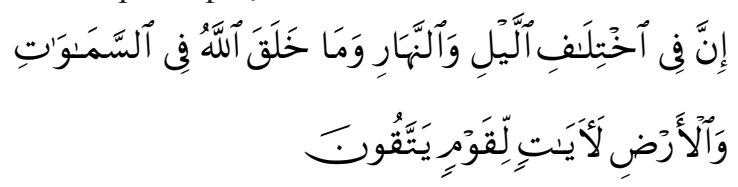

Sejak dulu sampai sekarang NU selalu menggunakan rukyat sebagai metodenya, dan dengan adanya bukti bahwa bisa di rukyat di Gebang, berarti kita sebagai orang nahdliyyin wajib mengikutinya. Tidak dilihat dari PBNU atau PWNU, terus kenapa ko' pas ada laporan dari PWNU tidak ditanggapi PBNU? ". ${ }^{29}$

Hal senada dikatakan oleh Hariri:

"Karena pada waktu itu di Gebang sudah melaksanakan rukyat, jadi saya selaku warga nahdliyyin mengikuti hasil rukyat itu yang sudah diajarkan Nabi. Waktu itu sudah melapor ke PBNU tapi prosesnya

28 Ibid., 5 dan 7.

29 Amin, wawancara, 23 September 2007. tidak diteruskan. Padahal disana sudah disumpah oleh Pengadilan Agama ". ${ }^{30}$

Dasar hukum yang menjadi doktrin yang sudah melekat pada beberapa pengurus NU yang mempunyai pendapat di atas adalah sebuah hadits ${ }^{31}$ yang memerintahkan puasa dan berbuka dengan melaksanakan melihat hilâl (rukyat). Selain itu, yang mereka ketahui bahwa sejak dulu hingga sekarang organisasi keagamaan NU menggunakan rukyat sebagai metode dalam menentukan awal bulan Syawal. Oleh karena itu menurut mereka ketika ada orang yang berhasil melaksanakan rukyat maka haruslah diikuti.

Menanggapi hal di atas, secara garis besar terdapat 2 macam sistem atau metode penentuan awal bulan Qomariyah (awal Syawal khususnya), yaitu: ${ }^{32}$ (1) Sistem rukyat bil fi'li, (2) Sistem hisab. Dan ada tiga jenis sistem hisab yang dipergunakan, yaitu: (1) Hisab urfi, (2), Hisab istilahi, (3) Hisab haqiqi.

Dalam perkembangannya sistem hisab haqiqi dapat diklasifikasikan menjadi tiga kelompok, yaitu (1) Hisab haqiqi bit-taqrib; Adapun yang dapat dikelompokkan dalam sistem hisab haqiqi bit-taqrib ini adalah kitab Sullamun al-Nayyiroin, Tadzkirah alIkhwan, al-Qowaidul Falakiyah dan beberapa kitab yang membahas hisab, (2) Hisab haqiqi bit-tahqiq; Metode hisab Badi'atul Mitsal, Khulashatul Wafiyah, Nurul Anwar dan sejenisnya dihitung masuk dalam kategori ini, dan (3) Hisab kontemporer; Beberapa metode yang masuk dalam kelompok ini adalah Ephimeris, Neutical Almanac dan sejenisnya.

Sedangkan mengenai metode yang digunakan oleh mereka sebagai pengurus organisasi keagamaan NU adalah sebagaimana yang biasa dijadikan pedoman oleh organisasi keagamaan NU sendiri dalam menentukan awal bulan Qomariyah. Yaitu lebih mengedepankan metode rukyat bil fi'li dan menfungsikan metode hisab sebagai pendukung dalam melaksanakan rukyat. Metode hisab yang digunakan oleh organisasi keagamaan NU pun tidak semua yang digunakan. Hanya hisab haqiqi bit-taqrib, hisab haqiqi bit-tahqiq, hisab kontemporer yang digunakan. Kemudian jika rukyat tidak berhasil, maka menggunakan metode istikmâl. Adapun dasar yang digunakan oleh organisasi keagamaan NU terkait penentuan awal bulan Qomariyah (khususnya Syawal) adalah sabda Nabi yang berbunyi:

\footnotetext{
30 Hariri, wawancara, 22 September 2007.

31 Diriwayatkan oleh Bukhari Muslim.

32 Pedoman Perhitungan Awal Bulan Qomariyah: Dengan Ilmu Ukur Bola (Jakarta: Bagian Proyek Pembinaan Administrasi Hukum Dan Peradilan Agama, 1983), 6-9.
} 


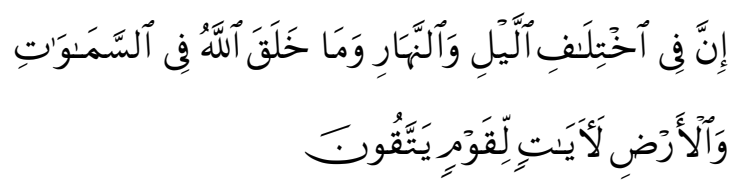

Alasan mereka memilih hasil rukyat di P. Gebang harus diikuti karena dikuatkan oleh SK PBNU Nomor: 311/A.II.04.d/I/1994

Pasal I ayat b:

"Bahwa penetapan awal Ramadhan, awal Syawal dan awal Dzulhijjah yang berlaku umum bagi segenap lapisan kaum muslimin di Indonesia dilakukan oleh pemerintah (Itsbatul Hakim). Oleh sebab itu agar diupayakan semaksimal mungkin adanya Penyelenggaraan Rukyat yang disaksikan oleh petugas pemerintah (Dep. Agama)", 33

Beberapa pengurus NU ini juga kecewa dengan sikap dari PBNU yang tidak mempertimbangkan hasil rukyat di P. Gebang. Padahal menurut mereka orang yang melakukan rukyat tersebut telah disumpah oleh Pengadilan Agama setempat. Terkait dalam menerima rukyat, ada beberapa syarat yang harus dipenuhi. Yaitu sebagai berikut: ${ }^{34}$ pertama, pelaku rukyat itu harus adil dalam persaksiannya, kedua, pelaku rukyat mengucapkan kalimat syahadat terlebih dahulu sebelum melakukan rukyat, dan ketiga, dalam memberi syahadat, pelaku rukyat harus didampingi oleh dua orang saksi yang adil pula. Oleh sebab itu wajarlah jika mereka sangat percaya dan taqlid terhadap hasil rukyat dari PWNU Jawa Timur. Karena pendapat mereka juga mempunyai dasar dan alasan yang kuat.

Dengan adanya dualisme perbedaan penentuan awal bulan Syawal 1427 H di organisasi NU, mereka agak menyayangkan hal tersebut terjadi. Hal ini terlihat dari yang dipaparkan oleh Hariri dan Amin yang mengatakan bahwa hasil rukyat tersebut sudah dilaporkan ke PBNU akan tetapi tidak ditindaklanjuti oleh PBNU. Dengan adanya fakta dan alasan-alasan tersebut, mengindikasikan bahwa belum adanya rasa kesolidan antar pengurus organisasi NU. Seringkali konsep syari'ah yang terbangun dan diperjelas dalam al-Qur'an menjadi perdebatan keras oleh para pemeluknya. Dan kontroversi selalu mengiringi kehidupan umat manusia didunia. Tapi sabda Rasulullah

\footnotetext{
33 Keputusan Pengurus Besar Nahdlatul Ulama tentang Pedoman Penyelenggaraan Rukyat Bil Fi'li.

34 Pedoman Rukyat dan Hisab Nahdlatul Ulama (Lajnah Falakiyah Pengurus Besar Nahdlatul Ulama, 2006), 30.
}

dalam sebuah haditsnya menyebutkan bahwa segala bentuk perbedaan akan membawa keberkahan bagi umatnya.

\section{Adanya Kesalahan Dalam Praktek Rukyat}

Mengenai penyebab yang kedua ini tidak semua pengurus organisasi keagamaan NU mengetahui. Hal ini karena mereka menganggap bahwa jika hasil rukyat disumpah oleh Pengadilan Agama, maka validitas hasilnya tidak diragukan lagi. Karena dengan disumpah oleh Pengadilan Agama, maka hasil tersebut memiliki bukti yang kuat dan kekuatan hukum. Tetapi ada juga beberapa pengurus organisasi NU yang mengetahui adanya kesalahan dalam praktek rukyat yang dilaksanakan di P. Gebang. Seperti Ahmad yang mengatakan:

"Setelah kulo nderek halaqoh wonten Malang kale pertemuan Internasional teng Semarang, pemateri ngendikaaken setelah hari raya pimpinan Lajnah Falakiyah Jawa Timur dan sekretaris ngecek praktek kembali tentang rukyat di Gebang. Setelah itu setelah datang dilokasi, dimana bapak berdiri? Di sini, sekarang arah hilalnya dimana? Di sana, loh nunjuknya itu keliru. Setelah dicek ngangge kompas itu angsal ler, padahal Oktober sebelah selatan dari titik barat. Nanging pengecekan setelah hari raya dados mboten mampu ngeceknya. Menurut ilmu de'e tasih $0^{\circ} 30^{\prime}$, berarti $1 / 2^{\circ}$ paling 2 menit umpomo ketho', niki mboten kengeng dilihat sebab sorot matahari lebih kuat dari pantulan sorot hilal, berarti nggeh mboten mungkin dirukyat ". (Setelah saya mengikuti halaqah di Malang dan pertemuan internasional di Semarang, pemateri mengatakan setelah hari raya pimpinana Lajnah Falakiyah Jawa Timur dan sekretaris ngecek praktek kembali tentang rukyat di Gebang. Setelah itu setelah datang dilokasi, dimana bapak berdiri? Di sini, sekarang arah hilalnya dimana? Di sana, loh nunjuknya itu keliru. Setelah dicek menggunakan kompas itu ternyata arah utara, padahal Oktober sebelah selatan dari titik barat. Tetapi pengecekan setelah hari raya jadi tidak mampu ngeceknya. Menurut ilmu beliau masih $0^{\circ} 30^{\prime}$, berarti $1 / 2^{\circ}$ paling 
2 menit apabila terlihat, ini tidak bisa dilihat sebab sorot matahari lebih kuat dari pantulan sorot hilal, berarti ya tidak mungkin dirukyat). ${ }^{35}$

Adanya pernyataan diatas menunjukkan bahwa terdapat kesalahan dalam menentukan arah keberadaan hilal. Padahal inilah yang sangat urgen dalam mengawali proses rukyat. Dari sini sudah terlihat adanya sebuah kesalahan yang fatal dan kecerobohan yang berdampak pada terjadinya perbedaan penentuan awal bulan Syawal 1427 H kemarin. Sehingga dapat dipastikan rukyat al-hilâl yang dilaksanakan di Gebang Madura adalah rukyat yang sangat diragukan kebenarannya.

Hal ini senada dengan keterangan dari Lajnah Falakiyah Jawa Timur yang menerangkan bahwa terdapat dua hal pokok terjadinya kesalahan dalam proses rukyat tersebut. Yaitu: ${ }^{36}$ (1) Dilihat dari posisi hilâl, semua perhitungan sepakat bahwa letak posisi hilâl di bulan Oktober berada di sebelah selatan khatulitiwa, tepatnya berada sekitar $14^{\circ} \mathrm{LS}$. Akan tetapi menurut KH. Jaelani sebagai saksi yang melihat hilâl mengatakan bahwa letak hilâl berada bukan di sebelah selatan. Berdasarkan hal itulah Lajnah Falakiyah Wilayah Jawa Timur ${ }^{37}$ melakukan reka ulang untuk mengecek kebenaran dari kesaksiannya. Perwakilan LF JATIM mengajak beliau ke tempat lokasi rukyat dan meminta tolong untuk menunjukkan arah beliau melihat hilal, kemudian beliau menunjukkan posisi hilal. Setelah itu, perwakilan LF JATIM mengukur garis arah utara, selatan, barat dan timur dengan menggunakan kompas. Berdasarkan pengukuran tersebut ternyata letak hilâl sesuai yang ditunjukkan oleh KH. Jaelani berada di sebelah utara khatulistiwa, tepatnya sekitar $2^{\circ}$ (derajat). Padahal semua perhitungan menunjukkan letak hilâl berada $14^{\circ}$ (derajat) di sebelah selatan, berarti terpaut $16^{\circ}$ (derajat). Hal ini sangat tidak mungkin karena di dalam kitab Tuhfat al-Muhtâj disebutkan jikalau seorang saksi yang melihat hilâl menerangkan bahwa posisi hilâl dihari pertama $14^{\circ}$ LS kemudian dihari kedua berpindah menjadi $2^{\circ}$ LU. Oleh karena itu kesaksian tersebut kurang cermat, (2) Dari terlihatnya hilâl, hampir semua perhitungan sepakat bahwa batas maksimal hilâl bisa terlihat yaitu pukul 17:36 WIB. Ketika itu maghrib di daerah Bangkalan sekitar pukul 17:26 WIB. Berdasarkan hisab tahkiki yang digunakan oleh LFNU menyatakan hilâl bisa dilihat sekitar selama 4 menit, jika pukul 17:26 WIB

\footnotetext{
35 Ahmad, wawancara, 22 September 2007.

36 Shofiyullah, wawancara, 4 Oktober 2007.

37 Pada pembahasan selanjutnya disingkat menjadi LF JATIM
}

tenggelam, maka sekitar pukul 17:30 hilâl sudah tidak bisa dilihat. Adapun hisab tertinggi adalah hitungan Sullam al-Nayyirain yang menyatakan bahwa hilâl berada di atas ufuk selama sekitar 14 menit. Jika berdasarkan Sullam al-Nayyirain, maka seharusnya hilâl terbenam pukul 17:36 WIB. Akan tetapi kesaksian hilâl tersebut terlihatnya pukul 17:38 WIB dimana pada saat tersebut berdasarkan semua perhitungan menyatakan hilâl sudah terbenam.

Hal ini juga tertulis dalam buku Lajnah Falakiyah Pengurus Besar Nahdlatul Ulama yeng mengemukakan adanya beberapa masalah yaitu: ${ }^{38}$ (1) Dilaporkan oleh perukyat, KH. M. Djaelani Chudlori dan Prof. Dr. KH. Hasanuddin, SH., MM., MBA., bahwa waktu melihat hilâl pukul 17:38 WIB atau 17:35 WIB selama 10-30 detik dan sebagai pendukung rukyat tersebut perukyat menggunakan data hisab metode Sullam anNayyirain, yang menyebutkan ghurûb as-syams pukul 17:24:08 WIB. Padahal menurut metode ini tidak mengenal ghurûb as-syams dan selalu mengatakan maghrib pukul 18:00 WIB. Jadi kalau melihat pukul 17:38 WIB, berarti hilâl belum waktunya dilihat, tetapi dilaporkan melihat. (2) Para astronom mengatakan, bahwa menurut penelitian saat ini di sekitar bulan terdapat benda angkasa lain (Jupiter dan Merkurius) dan cahaya matahri 25 juta kali lebih kuat dari pada cahaya bulan yang lemah, sehingga hilâl sulit dilihat. Kalaupun ada yang melapor melihat hilâl, hal itu kemungkinan melihat cahaya benda langit lain atau bias pandangan, dan (3) Secara astronomi keadaan hilâl di Bangkalan pada waktu itu belum memenuhi kriteria imkan ar-rukyat menurut metode hisab yang tingkat akurasinya tinggi seperti Mawaqit.

Menurut metode Mawaqit karya Dr. Ing. H. Khafid anggota Litbang Lajnah Falakiyah Pengurus Besar Nahdlatul Ulama, tinggi hilâl di Gebang Bangkalan pada waktu itu baru mencapai $0^{\circ} 14 ' 58,4$ '. Kesepakatan MABIMS tahun 1992, kriteria imkan ar-rukyat yang dapat diterima minimal tinggi hilâl $2^{\circ}$ (derajat), umur bulan pukul 8 , jarak matahari ke bulan $3^{\circ}$ (derajat), menurut data hisab yang tingkat akurasinya tinggi bukan menurut data hisab yang tingkat akurasinya rendah seperti Sullam an-Nayyirain dan sejenisnya.

Hal ini sangat bertentangan dengan fakta yang terjadi, rukyatyang dilaksanakan di Gebang Bangkalan pada pukul 17:38 WIB. Padahal hasil semua hisab menunjukkan bahwa ghurûb as-syams sekitar pada pukul 17:24 WIB. Sangat disadari bahwa melakukan

38 Laporan Lajnah Falakiyah Kepada PBNU Tentang Penyelenggaraan Rukyat Untuk Idul Fitri 1427 H., Op. Cit., 11. 
rukyat bukan suatu pekerjaan yang mudah. Akan tetapi sangatlah disayangkan jika seorang yang melakukan rukyat tanpa mempertimbangkan hasil hisab sebagai pembantu dalam melaksanakan rukyat. Padahal jika berdasarkan tingkat keilmuan yang mereka miliki, kecil kemungkinan terjadi kesalahan dalam prktek rukyat dan tentu mereka akan mempertimbangkan hal tersebut untuk validitas hasilnya.

\section{Dampak Sosiologis Masyarakat Nahdliyyin Keca- matan Banyuwangi Terkait dengan Perbedaan Penentuan Awal Bulan Syawal 1427 H}

Melihat beberapa alasan tentang penyebab perbedaan penentuan awal bulan Syawal 1427 H maka berdasarkan data-data yang ditemukan, terdapat banyak perbedaan dampak yang mereka rasakan. Hal ini karena adanya pengelompokan sosial di kalangan masyarakatnahdliyyin Kecamatan Banyuwangi secara tidak langsung. Peneliti mengklasifikasikan menjadi dua golongan berdasarkan pengetahuan mereka terkait penyebab perbedaan penentuan awal Syawal $1427 \mathrm{H}$ yang menimbulkan beberapa dampak berbeda yang mereka rasakan. Yaitu antara kelompok awam (kelompok masyarakat nahdliyyin) dan kelompok elit agama $^{39}$ (tokoh masyarakat dan pengurus organisasi keagamaan NU).

Mayoritas kelompok masyarakat nahdliyyin yang tidak masuk dalam struktur kepengurusan organisasi keagamaan NU hanya mampu mengikuti tokoh masyarakat nahdliyyin dan langgar/musholla setempat tanpa mengetahui dasar yang digunakan (taqlid). Mereka menjadikan salah satu tokoh masyarakat setempat sebagai patokan mereka dalam melaksanakan hari raya. Apa yang menjadi keputusan dan ketetapan tokoh masyarakat tersebut, maka mereka langsung mengikutinya tanpa mempertimbangkan validitas hasilnya. Seperti ibu Aminah yang mengatakan:

"Saya kan ngga'ngerti dengan begituan
(rukyat-hisab), jadi ya saya pokoknya
mengikuti apa kata pak kyai. Pak kyai
ngomong senin, ya saya ikut senin, pak
kyai ngomong selasa, ya saya ikut selasa.
Rata-rata orang-orang disini juga ikut
pak kyai". ${ }^{40}$

Dari sini terlihat bahwa adanya rasa kepercayaan yangsangattinggiterhadapseseorangyangmempunyai

\footnotetext{
39 Elit adalah orang-orang terbaik atau golongan orang yang terpilih atau terpelajar atau terpandang dalam masyarakat. Dalam penelitian ini yang tertulis adalah di kalangan elite agama, maka yang dimaksud adalah golongan terpelajar dalam bidang agama di suatu masyarakat.

40 Aminah, wawancara, 25 Agustus 2007.
}

nilai lebih di masyarakat. Mereka menganggap bahwa apapun yang dilakukan oleh tokoh masyarakat adalah benar dan harus dilaksanakan. Sehingga berawal dari rasa kepercayaan yang tinggi menimbulkan rasa kepatuhan terhadap tokoh masyarakat tersebut. Adanya rasa solidaritas sosial sangat kuat antara sesama golongan nahdliyyin yang didasarkan pada perasaan moral dan kepercayaan yang dianut bersama yang diperkuat oleh pengalaman emosional bersama juga terlihat disini.

Selain mereka ber-taqlid kepada tokoh masyarakat setempat, mereka juga menggunakan langgar setempat sebagai patokan untuk mereka dalam melaksanakan hari raya. Jika langgar/musholla dan warga sekitar melaksanakan hari raya pada hari Senin, maka mereka langsung mengikutinya. Bila langgar/musholla dan warga sekitar melaksanakan hari raya pada hari Selasa, maka mereka pun langsung mengikutinya. Hal ini disebabkan minimnya pengetahuan agama mereka serta ilmu mengenai sistem penentuan awal Syawal. Bapak Sapuan sebagai salah satu masyarakat nahdliyyin yang tidak masuk dalam struktur kepengurusan organisasi keagamaan NU yang ketika ditanya alasan mengikuti hari raya Selasa, beliau menjawab: "kulo pokoke nderek sareng-sareng tiangtiang mriki pun teng Langgar". ${ }^{41}$ (saya pokoknya ikut bersama-sama dengan orang-orang disini di Musholla). Hal ini senada yang diungkapkan oleh bapak Wiyono: "aku ambe' wong-wong kene melok Langgar ae". ${ }^{2}$ (saya dan orang-orang disini ikut Mushola aja). Begitu juga dengan ibu Masidah yang menyatakan: "waktu itu saya ikut langgar sini". ${ }^{43}$

Menurut Robert Bierstedt, kelompok jenis pertama ini dinamakan kelompok kemasyarakatan yang merupakan kelompok yang hanya memenuhi satu persyaratan, yaitu kesadaran akan persamaan di antara mereka. ${ }^{44}$ Adanya beberapa jawaban di atas menunjukkan bahwa mereka termasuk dalam anggota tipe masyarakat yang bersama-sama mempunyai kesadaran menganut agama yang sama, oleh karena itu keanggotaan mereka dalam masyarakat dan dalam kelompok keagamaan adalah sama. Masyarakat ini berpendapat bahwa agama memasukkan pengaruhnya yang sakral ke dalam sistem nilai masyarakat secara mutlak, hal ini terlihat dari kekuatan pengaruh Musholla/Langgar yang besar bagi keyakinan mereka. Sehingga dari sini terlihat bahwa bagi ke-

\footnotetext{
41 Sapuan, wawancara, 22 Agustus 2007.

42 Wiyono, wawancara, 20 agustus 2007.

43 Masidah, wawancara, 19 agustus 2007.

44 Kamanto Sunarto, Pengantar Sosiologi (Jakarta: Lembaga Penerbit Fakultas Ekonomi Universitas Indonesia, 2004) 130.
} 
lompok pertama ini sangat kecil kemungkinan terbukanya peluang untuk melakukan ijtihad. Hal ini karena didalam kelompok ini belum ada kontak dan komunikasi di antara anggota, dan juga belum ada organisasi.

Hal ini dikuatkan dengan teori Emile Durkheim tentang klasifikasi solidaritas sosial di masyarakat menjadi dua, yaitu solidaritas mekanik dan solidaritas organik. Menurut Durkheim bahwa masyarakat di atas masuk dalam katagori solidaritas mekanik dengan ciri yang menandai masyarakat yang masih sederhana, yang oleh Durkheim dinamakan segmental. ${ }^{45}$ Dalam masyarakat yang menganut solidaritas mekanik, yang diutamakan adalah persamaan prilaku dan sikap. Seluruh warga masyarakat didasarkan pada suatu "kesadaran kolektif" bersama (collective conscience), yaitu suatu kesadaran bersama yang menyangkut keseluruhan kepercayaan dan perasaan kelompok, dan bersifat ekstern serta memaksa. Itu merupakan suatu solidaritas yang tergantung pada individu-individu yang memiliki sifat-sifat yang sama dan menganut kepercayaan dan pola normatif yang sama pula. Karena itu, individualitas tidak berkembang.

Adapun sanksi yang diberikan terhadap pelanggaran hukum terhadap masyarakat ini bersifat menekan (represif). Sanksi-sanksi ini diberikan bila mengancam atau melanggar kesadaran kolektif yang kuat itu. Hal ini sesuai dengan gambaran masyarakat nahdliyyin kecamatan Banyuwangi yang memiliki tingkat keilmuan minimum. Mereka memberikan sanksi dengan anggapan bahwa orang yang melaksanakan hari raya pada hari yang berbeda maka orang tersebut dianggap bukan orang nahdliyyin. Mereka tidak mempertimbangkan apapun dalam hal ini.

Sanksi tersebut diungkapkan oleh ibu Aminah dalam penuturannya:

"disini itu orang yang lebaran senen dianggap ya orang muhammadiyah". ${ }^{46}$

Begitu juga bapak Wiyono mengatakan:

"poko'e lek ono wong sek bedo teko wong-wong nang kene, mesti wong iku ikut muhammadiyah paling". ${ }^{47}$ (pkoknya kalau ada orang yang berbeda dari orang-orang sekitar, maka pasti orang tersebut mengikuti muhammadiyah).

\footnotetext{
45 Doyle Paul Johnson, "Sosiological Theory Classical Founders and Contemporary Perspectives", diindonesiakan Robert M. Z. Lawang, Teori Sosiologi Klasikdan Modern (Cet. II; Jakarta: PT Gramedia, anggota IKAPI, 1988), 183.

46 Wiyono, wawancara, 20 Agustus 2007.

47 Aminah, wawancara, 25 Agustus 2007.
}

Dengan adanya dualisme perbedaan penentuan awal bulan Syawal 1427 H, mereka merasakan dampaknya. Hal ini karena minimnya kemampuan keilmuan agama yang mereka miliki. Mereka merasakan langsung dampak perbedaan tersebut dalam kehidupan mereka tanpa mengerti penyebabnya. Dalam hal ini bapak Wiyono mengatakan:

\section{"Aku bingung, soale waktu senen iku ono wong arep unjung-unjung (silaturrahmi) mrene tapi kerono aku sek puoso, ya wes akhire ta 'tutup omahku". ${ }^{48}$ (saya bingung, karena waktu senin itu ada orang yang mau silaturrahmi kesini tapi karena saya masih puasa, akhirnya pintu rumah saya tutup).}

Bapak Suratmin juga mengatakan:

"Ya waktu itu resah, terus mencari info dari daerah Wonsorejo yang sudah ada takbiran, setelah tahu ada daerah sebelah takbiran, maka saya ikut takbiran dan besoknya saya lebaran". ${ }^{49}$

Ibu Masruroh dalam penuturannya:

"tetangga saya itu hari rayanya hari senin, saya bingung ko'mereka kayak gitu. Terus saya bilang ke orang-orang dan kata orang-orang ko' sewang-sewangan (berbeda) gitu seh? ya itu terus orang itu banyak yang ngerasani (gunjingkan)". 50

Hal senada juga dikatakan oleh bapak Sapuan: "kerono kulo tiang bodoh, dados kulo nderektiang-tiangmriki.Lekmbotennderek tiang-tiang mriki, kulo wedhi dirasani kale tiang mriki". ${ }^{51}$ (karena saya orang yang bodoh, jadi saya ikut orang-orang sekitar. Kalau tidak ikut dengan orang-orang sekitar, saya khawatir digunjingkan).

Pak Abdurraman mengatakan:

"saya kan ikut hari senin, terus saya dimenengi (tidak disapa) sama pak RT, terus dia bilang saya bikin kesruh (ribut). Padahal saya lebarannya diam saja dirumah". ${ }^{52}$

Lain halnya dengan ibu Apid yang mengatakan: "waktu dino seloso aku ndelok ulan (bulan)

\footnotetext{
48 Wiyono, wawancara, 20 Agustus 2007.

49 Suratmin, wawancara, 21 Agustus 2007.

50 Masruroh, wawancara, 23 Agustus 2007.

51 Sapuan, wawancara, 22 Agustus 2007.

52 Abdurrahman, wawancara, 24 Agustus 2007.
} 
tidak sebundar seperti tanggal siji, aku dadi yakin lek tanggal siji iku senin. Tapi aku wingi kan lebaran seloso, terus lek ngono iku piye yo endane?". 53 (waktu hari selasa saya melihat bulan tidak sebundar seperti tanggal satu, jadi waktu itu saya yakin kalau hari rayanya hari senin, tapi saya kemarin sudah terlanjur mengikuti hari raya hari selasa, terus kalau seperti itu bagaimana?).

Dan ibu Latifah pun mengatakan hal yang berbeda dalam penuturannya:

"kalo biasanya aku ikut mak (ibu) tapi
tahun yang kemarin ini aku ikut sama
suamiku. Soalnya sampai malam senin
iku kan masih ruwet beritanya, jadi
daripada gitu ya wes aku besoknya
ikut suamiku sholat di lapangan. Kan
kalo disini iku yang sholat di lapangan
biasanya muhammadiyah. "54

Berdasarkan pernyataan-pernyataan di atas dapat disebutkan beberapa dampak yang timbul dari dualisme perbedaan penentuan awal bulan Syawal $1427 \mathrm{H}$ di organisasi keagamaan NU. antara lain: (1) Kebingungan di antara mereka sampai menolak orang lain yang bersilaturrahmi kerumahnya, (2) Resah dan berusaha mencari informasi ke daerah lain, (3) Menjadi bahan gunjingan masyarakat sekitar, (4) Adanya sikap tertekan dan terpaksa, (5) Tidak disapa oleh warga lainnya, (6) Timbulnya keraguan dalam melaksanakan hari raya, (7) Timbulnya ketidakpercayaan warga nahdliyyin terhadap keputusan organisasi keagamaan NU, dan (8) Kebingungan dalam membayar zakat fitrah. ${ }^{55}$

Kelompok yang kedua adalah tokoh masyarakat dan pengurus organisasi keagamaan NU (kelompok elite agama). Dalam menentukan awal bulan Syawal, mayoritas mereka mengetahui metode yang digunakan. Sehingga sebagai pemimpin umat sudah barang tentu memiliki pijakan agama dalam melakukan tindakan. Melalui tindakan inilah merupakan sumbangan terbesar yang dilakukan oleh para tokoh masyarakat dan pengurus NU sebagai golongan elit agama. Sebagaimana bapak Masykur mengungkapkan alasannya:

"Karena saya jadi pimpinan organisasi, tentunya saya taat kepada organisasi induk saya yaitu PBNU. Karena kemarin

\footnotetext{
53 Apid, wawancara, 26 Agustus 2007.

54 Latifah, wawancara, 26 Agustus 2007.

55 Mayoritas masyarakat nahdliyyin menganggap bahwa membayar zakat fitrah harus akhir Ramadhan atau malam Syawal.
}

kan ada dua hari raya, yang pertama diputuskan pengurus besar melalui itsbat dan yang kedua yang diputuskan oleh $P W N U$. Karena PWNU melihat bulan yang di Bangkalan itu. Oleh karena itu kami sebagai pimpinan organisasi $N U$ Banyuwangi masih tetap mengikuti keputusan pengurus besar NU berarti saya hari raya hari Selasa". ${ }^{56}$

Sedangkan menurut bapak Nashir:

"Karena hingga detik-detik terakhir, yang saya ketahui hasil itsbat itu tidak satupun yang melihat hilal waktu itu, sedangkan saya punya keyakinan berpuasa dan berbuka dengan melihat hilal ". ${ }^{57}$

Bapak Hadi juga menyatakan:

"Saya mengikuti sabda nabi yang berbunyi:

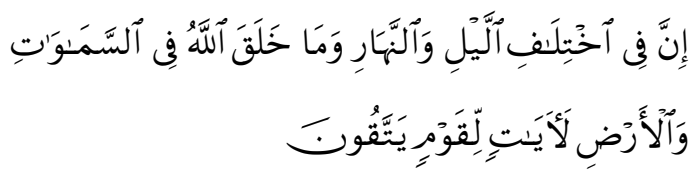

Dengan beberapa alasan di atas menggambarkan bahwa terdapatnya peluang untuk berbeda terkait penentuan awal Syawal 1427 H. sehingga peluang untuk berijtihad dalam kelompok ini sangat besar. Hal ini disebabkan kemampuan keilmuan yang mereka miliki. Dari sini juga terlihat adanya rasa kepatuhan terhadap orang yang mempunyai kekuasaan. Akan tetapi hal yang membedakan dari kelompok sebelumnya adalah dalam melaksanakan keputusan tersebut disertai dengan bukti dan alasan yang kuat. Sehingga mereka yakin dan mampu mempertanggungjawabkan validitas hasilnya.

Senada dengan klasifikasi dari Robert Bierstedt, jenis kelompok asosiasi adalah para anggotanya mempunyai kesadaran jenis dan dijumpai adanya persamaan kepentingan pribadi maupun kepentingan bersama. Di samping itu di antara para anggotanya dijumpai adanya hubungan sosial, adanya kontak dan komunikasi. Selain itu dijumpai pula adanya ikatan organisasi formal. ${ }^{58}$

Hal ini sesuai dengan kelompok yang kedua ini. Mereka berawal dari adanya kesadaran yaitu mempunyai tujuan dan ide yang sama yaitu ingin menye-

\footnotetext{
56 Masykur, wawancara, 1 September 2007.

57 Nashir, wawancara, 25 Agustus 2007.

58 Kamanto Sunarto, Op. Cit., 130.
} 
lamatkan dan mensejahterakan umat dan akhirnya membentuk suatu kelompok elit agama. Dimana di dalam tujuan dan ide yang sama juga dijumpai kepentingan pribadi yaitu untuk memperdalam kemampuan ilmu yang mereka miliki dengan melalui organisasi keagamaan NU.

Secara umum, interaksionisme simbolik memusatkan pada proses mikro, atau interaksi aktual yang terjadi antara orang perorang melalui level kemungkinan terendah. Mereka membuat kasus yang mana proses mikro menciptakan struktur makro pada masyarakat, tetapi mereka tidak memerinci ide ini dengan baik, dan secara umum mereka juga mengakui dampak yang berlawanan. Pengaruh struktur makro pada proses mikro. Teori strukturasi didesain sebagai penjelasan yang lebih komplit dari hubungan mikro dan makro. ${ }^{59}$

Teori strukturasi, menurut gagasan sosiologis, Anthony Gidden dan pengikutnya adalah teori umum dari aksi sosial.Teori ini menyatakan bahwa manusia adalah proses mengambilkan dan meniru beragam sistem sosial. Komunikator bertindak secara strategis berdasarkan pada peraturan untuk meraih tujuan mereka dan oleh sebab itu menciptakan struktur yang kembali untuk mempengaruhi aksi selanjutnya. Struktur mirip dengan hubungan pengharapan, peran grup dan norma-norma, jaringan komunikasi dan institusi kemasyarakatan keduanya berpengaruh dan dipengaruhi oleh aksi sosial. Struktur ini menyediakan setiap individu-individu dengan peraturan yang membimbing tindakan mereka, tetapi tindakan bertujuan membuat peraturan baru dan meniru pendahulunya. ${ }^{60}$

Mereka melakukan sebuah tindakan secara sengaja untuk menyelesaikan tujuan-tujuannya, pada saat yang sama, tindakan mereka memiliki "unintended consequenses" (konsekuensi yang tidak disengaja) dari penetapan struktur yang berdampak pada tindakan mereka selanjutnya. Ketika salah satu pengurus NU melakukan perbedaan dalam melaksanakan hari raya, mereka kurang menyadari akan dampak-dampak dari tindakan dan konsekuensi strukturnya. Yang pertama, satu struktur bisa menengahi, yang lain, sebaliknya, produksi dari satu struktur dilengkapi dengan memproduksi yang lain. Di sini, peran struktur memerlukan penegakan strukturyang lainyang tidak dapat ditentukan mana yang pertama. Hal ini adalah permasalahan paradoks klasik. Pertentangan memicu konflik, dan

\footnotetext{
59 http://teorikomunikasi-umy.blogspot.com/2005/09/teori-tentang-interaksisimbolik

60 www.gatra.com, 22 Oktober 2007
}

melalui, dialek dan ketegangan antara elemen yang bertentangan, perubahan sistem dihasilkan. ${ }^{61}$

Dampak yang mereka rasakan sangat signifikan dibandingkan kelompok lain. Hal ini disebabkan karena sebagai pemimpin umat, keputusan dan tindakan mereka selalu menjadi patokan bagi umat. Ketika terjadi dualisme perbedaan dalam penentuan awal bulan Syawal 1427 H, mereka menjadi acuan dan tempat bertanya atas kebingungan dan keresahan masyarakat nahdliyyin. Padahal mereka juga mengalami hal yang sama. Adapun dampak yang terjadi pada kelompok ini yaitu, (1) Pertengkaran antara pengurus organisasi keagamaan NU, (2) Selama 24 jam pengurus NU harus menjelaskan kepada masyarakat nahdliyyin yang bertanya tentang dualisme perbedaan penentuan awal Syawal $1427 \mathrm{H}$, (3) Pengurus organisasi keagamaan NU dianggap kurang pandai oleh masyarakat nahdliyyin dalam menentukan awal Syawal, dan (4) Tokoh masyarakat harus mendamaikan antar warga nahdliyyin yang bertengkar karena dualisme perbedaan tersebut.

Dari uraian di atas dapat diklasifikasikan sebagai berikut (Tabel I):

\section{Kesimpulan}

Dari pembahasan di atas dapat di ambil kesimpulan sebagai berikut: Pertama, Kalangan pengurus NU menganggap bahwa penyebab terjadinya dualisme perbedaan penentuan awal bulan Syawal $1427 \mathrm{H}$ di organisasi keagamaan Nahdlatul Ulama disebabkan oleh dua hal. Antara lain, (a) Adanya kesalahan teknis dalam penyebaran berita hasil rukyat, (b) Adanya kesalahan dalam praktek rukyat. Kedua, Dampak yang disebabkan oleh dualisme perbedaan penentuan awal bulan syawal $1427 \mathrm{H}$ di organisasi keagamaan NU berbeda-beda dan diklasifikasikan sebagai berikut: (1) Dampak yang terjadi di kalangan masyarakat nahdliyyin yang tidak masuk dalam struktur kepengurusan (masyarakat awam) antara lain: Kebingungan di antara mereka sampai menolak orang lain yang bersilaturrahmi kerumahnya, resah dan berusaha mencari informasi ke daerah lain, menjadi bahan gunjingan masyarakat sekitar, adanya sikap tertekan dan terpaksa, tidak disapa oleh warga lainnya, Timbulnya keraguan dalam melaksanakan hari raya, Timbulnya ketidakpercayaan warga nahdliyyin terhadap keputusan organisasi keagamaan NU, dan kebingungan dalam membayar zakat fitrah. (2) Dampak yang terjadi di kalangan elit agama antara lain: Pertengkaran antara pengurus

61 Ibid. 
Tabel 1

\begin{tabular}{|c|c|c|c|}
\hline No. & Golongan & Ciri-ciri & Sikap \\
\hline \multirow[t]{5}{*}{1.} & Elit & $\begin{array}{l}\text { Pengurus organisasi } \\
\text { keagamaan. }\end{array}$ & $\begin{array}{l}\text { Mengikuti intruksi organisasi, akan tetapi disertai } \\
\text { alasan. }\end{array}$ \\
\hline & & Mengerti agama. & Bisa mempertahankan pendapat \\
\hline & & Tokoh masyarakat. & Ikut menentukan keputusan masjid, mushola/ langgar. \\
\hline & & & Bisa mempertahankan pendapat \\
\hline & & & Bisa menghargai orang lain yang berbeda pendapat. \\
\hline \multirow[t]{6}{*}{2.} & Awam & Bukan pengurus organisasi. & Mengikuti intruksi organisasi, tanpa mengetahui alasan. \\
\hline & & Kurang mengerti agama. & Kurang bisa mempertahankan pendapat. \\
\hline & & Bukan tokoh masyarakat. & $\begin{array}{l}\text { Mengikuti keputusan dari masjid, mushola/ langgar } \\
\text { terdekat. }\end{array}$ \\
\hline & & & Kurang bisa mempertahankan pendapat. \\
\hline & & & Kurang bisa menghargai perbedaan. \\
\hline & & & Rawan konflik \\
\hline
\end{tabular}

organisasi keagamaan NU, selama 24 jam pengurus NU harus menjelaskan kepada masyarakat nahdliyyin yang bertanya tentang dualisme perbedaan penentuan awal Syawal 1427 H, Pengurus organisasi keagamaan NU dianggap kurang pandai oleh masyarakat nahdliyyin dalam menentukan awal Syawal, dan Tokoh masyarakat harus mendamaikan antar warga nahdliyyin yang bertengkar karena dualisme perbedaan tersebut.

\section{Saran}

Setelah mengamati dan memahami peneitian ini, ada hal yang perlu diperhatikan diantaranya: perlunya penyatuan metode hisab yang digunakan

\section{Daftar Pustaka}

Al-Qur'an al-Karim.

Abdullah, M. Amin, dkk. (2006) Metodologi Penelitian Agama (Pendekatan Multidisipliner), Yogyakarta: Lembaga Penelitian UIN Sunan Kalijaga.

Ad-Dimyathi, Abu Bakar Utsman bin Muhammad Syattha (t.th.) I'anat al-Thalibin, juz 2, Beirut: Darul Kutub al-Ilmiyyah.

Al-Anshori, Syamsudin Muhammad bin Abil Abbas al-Mishri (t.th.) Nihâyah al-Muhtaj, jilid III, Beirut: Darul Fikri.

Al-Jaziri, Abdurrahman (t.th.) Al-Fiqh 'ala alMadzâhib al-Arba'ah, jilid I, Beirut: Darul Kutub al-Ilmiyyah. oleh organisasi keagamaan NU baik di pengurus pusat maupun pengurus wilayah, kemudian diklat hisab rukyat dan pelatihan rukyat di lapangan yang selama ini sudah dilaksanakan perlu ditingkatkan dan diperluas. Jika memungkinkan, perlu diadakan program khusus pelatihan rukyat dalam teori dan praktik agar memperkecil kekeliruan dalam praktek rukyat di lapangan, selanjutnya agar lebih ditingkatkan rasa persatuan dan rasa solidaritas antar pengurus besar Nahdlatul Ulama dan pengurus wilayah Nahdlatul Ulama khususnya dan semua pengurus Nahdlatul Ulama umumnya, dan yang terpenting adalah lebih mengutamakan kemaslahatan masyarakat awam

Al-Mishri, Ali bin Abdul Kafi Abul Hasan Taqiyyuddin aas-Subki (t.th.) Al-Alam al-Mansyur fi Itsbat al-Syuhur, Jombang: Pesantren al-Aziziyyah alIslami.

An-Nawawi, Imam Abu Zakaria, Muhyiddin bin Syarof (1421 H) Al-Majmu', jilid VI, Beirut: Darul Fikri.

Daftar Isian Data Dasar Profil Kelurahan tahun 2006.

Dahlan, Abdul Aziz (ed.) et. al. (t.th.) Ensiklopedi Islam, Jakarta: PT. Ichtiar Baru van Hoeve.

Dahlan, Abdul Aziz (ed.) (2001) Ensiklopedi Hukum Islam, Jakarta: PT. Ichtiar Baru van Hoeve. 
Http://Teorikomunikasi-Umy. Blogspot. Com $/ 2005 / 09 /$ Teori-Tentang-InteraksiSimbolik, (diakses 22 Oktober 2007).

Ikhbar Pengurus Wilayah Nahdlatul Ulama Jawa Timur, 22 Oktober 2006.

Ikhbar Pemberitahuan Hasil Rukyatul Hilal bil Fi'li Awal Syawal 1427 H oleh PBNU, 22 Oktober 2006.

Johnson, Doyle Paul (1988) "Sosiological Theory Classical Founders and Contemporary Perspectives", diindonesiakan Robert M. Z. Lawang, Teori Sosiologi Klasik dan Modern, Cet. II, Jakarta: PT Gramedia.

Keputusan Pengurus Besar Nahdlatul Ulama tentang Pedoman Penyelenggaraan Rukyat Bil Fi'li.

LKP2M (2005) Research Book For LKP2M, Malang: UIN-Malang.

Moleong, Lexy J. (2005) Metodologi Penelitian Kualitatif (Edisi Revisi), Bandung: PT Remaja Rosdakarya.

Murtadho, Moh. (2004) Ilmu Hisab Praktis: DasarDasar Falakiyah, Malang: Fakultas Syari'ah UIN Malang.

Murtadho, Moh. (2005) Jurnal Ilmiah eL-Qisth, Volume 2, Nomor 1, September 2005, Malang: Fakultas Syari'ah UIN Malang.

Muslih, Moch. Choirul (2006) Analisis Terhadap Penggunaan Paradigma Penentuan Awal Bulan Qomariyah di Kalangan Ahli Hisab Malang (Kasus di Ponpes al-Asyrof, Ponpes Gading dan Muhammadiyah Malang), Skripsi Jurusan Ahwal Al-Syakhsyiah Universitas Islam Negeri (UIN) Malang.

Nasution, S. (1998) Metode Penelitian Naturalistik Kualitatif, Bandung: Tarsito.

Nawawi, Abd. Salam (2004) Rukyat Hisab di Kalangan NU Muhammadiyah, Surabaya: Diantama dan Lajnah Falakiyah NU Jatim.

Program al-Qur'an in word.

Soekanto, Soerjono (2002) Sosiologi suatu Pengantar,
Jakarta: PT Raja Grafindo Persada.

Sudjana, Nana dan Ahwal Kusuma (2001) Proposal Penelitian di Perguruan Tinggi, Bandung: Sinar Baru Algasindo.

Suprayogo, Imam dan Tobroni (2003) Metodologi Penelitian Sosial-Agama, Bandung: PT Remaja Rosdakarya.

Sunarto, Kamanto (2004) Pengantar Sosiologis, Jakarta: Lembaga Penerbit Fakultas Ekonomi Universitas Indonesia.

www.nu.or.id, (diakses 23 Juli 2007).

www.gatra.com, (diakses 22 Oktober 2007).

(1983)Pedoman Perhitungan AwalBulan Qomariyah: Dengan Ilmu Ukur Bola, Jakarta: Pembinaan Administrasi Hukum dan Peradilan Agama.

(1981) Almanak Hisab Rukyat, Jakarta: Proyek Pembinaan Badan Peradilan Agama Islam.

(1983)Pedoman Perhitungan Awal Bulan Qomariyah: Dengan Ilmu Ukur Bola, Jakarta: Bagian Proyek Pembinaan Administrasi Hukum Dan Peradilan Agama.

(2006) Pedoman Rukyat dan Hisab Nahdlatul Ulama, Jakarta: Lajnah Falakiyah Pengurus Besar Nahdlatul Ulama.

(2006) Laporan Lajnah Falakiyah Kepada PBNU tentang Penyelenggaraan rukyat untuk Idul Fitri 1427 H, Lajnah Falakiyah Pengurus Besar nahdlatul Ulama.

(2006) Laporan Lajnah Falakiyah Kepada PBNU Tentang Penyelenggaraan Rukyat Untuk Idul Fitri 1427 H, Lajnah Falakiyah Pengurus Besar Nahdlatul Ulama.

(1983)Pedoman Perhitungan AwalBulan Qomariyah: Dengan Ilmu Ukur Bola, Jakarta: Bagian Proyek Pembinaan Administrasi Hukum dan Peradilan Agama.

(2006) Pedoman Rukyat dan Hisab Nahdlatul Ulama, Lajnah Falakiyah Pengurus Besar Nahdlatul Ulama. 